sizing, to which great attention is being given at the present time. Although the conference will be primarily concerned with the physical principles of particle-size analysis, the development of new instruments and their use will receive attention, particular interest being attached to the systematic comparison of different methods of particle-size analysis. Papers describing original work are invited for reading and discussion at the conference, and synopses of such contributions should be sent before February 3 to the honorary secretary of the conference, Mr. R. L. Brown, at the Institute of Physics, 47 Belgrave Square, Isondon, S.W.I.

\section{Static Electrification: Conference in London}

THE Institute of Physics has arranged a conference on static electrification, which will be held at Bedford College, London, during March 25-27. Prof. F. A. Vick, of the University College of North Staffordshire, Stoke-on-Trent, will give the opening lecture, and the other sessions will each take the form of an introductory survey, followed by specialized papers and discussion. The introductory surveys will be given by Dr. P. S. Henry (general principles of the generation and dissipation of static electricity), $\mathrm{Mr}$. E. S. Shire (electrostatic machines) and Mr. H. W. Swann (harmful static electrification). The more specialized papers will be available as pre-prints to those attending the conference, and the proceedings of the conference will later be published by the Institute. Further information can be obtained from the conference secretary, Mr. N. Clarke, at the Institute of Physics, 47 Belgrave Square, London, S.W.I.

\section{University of London}

The title of reader in the University of London has been conferred on the following: Dr. N. A. Barnicot, in physical anthropology, in respect of the post held by him at University College; and Dr. J. M. Coulson, in chemical engineering, in respect of the post held by him at the Imperial College of Science and Technology. The degree of D.Sc. has been conferred on Mr. Harold Barnes.

\section{Announcements}

M. Jules BaIllaud, honorary director of the Pic du Midi Observatory and honorary astronomer of the Paris Observatory, has been elected a member of the Astronomy Section of the Paris Academy of Sciences in succession to the late B. Lyot.

ON the occasion of his retirement from the post of research professor in agriculture in the University of Sydney, Prof. W. L. Waterhouse has been elected an honorary life member of the Royal Agricultural Society of New South Wales, in recognition of his outstanding investigations on cereals.

Dr. F. A. Fox, formerly deputy director of the British Welding Research Association, has been appointed superintending scientist in charge of the Chemical and Physical Research Laboratories, Australian Government Department of Supply, Maribyrong, Melbourne.

THE following have been appointed to senior lectureships in the University of Sheffield: Dr. J. S. D. Bacon (biochemistry) and D. R. Wood (pharmacology).

Mr. P. Arthur Wells, deputy secretary of the Royal Sanitary Institute, has been appointed secretary of the Institute in succession to Dr. J. W.
Dudley Robinson, who has recently retired (see Nature, October 25, 1952, p. 693). Mr. Wells also becomes secretary of the Royal Sanitary Institute and Sanitary Inspectors Examination Joint Board and secretary of the National Nursery Examination Board. Previously he has been director of education to the International Wool Secretariat and general secretary of the Society of Dyers and Colourists.

THE Scottish Branch of the Science Masters' Association will hold its annual meeting at the Heriot-Watt College, Edinburgh, during April 7-10, with the principal of the College, Dr. H. B. Nisbet, as president. Other speakers will include Prof. G. F. Marrian, Dr. Neil Campbell, Dr. D. B. McIntyre, R. M. Sillitto, N. G. Matthews, G. Barclay and W. W. Fulton. Visits will be arranged to various places of scientific interest in the neighbourhood, and there will be exhibitions by members of the Association, publishers and manufacturers of scientific apparatus. Further details can be obtained from the organizing secretary, J. Turpie, Trinity Academy, Edinburgh 6.

A JoINT meeting of the Hospital Physicists' Association and the Industrial Radiology Group of the Institute of Physics is to be held at the Royal Institution, Albemarle Street, London, S.W.1, on January 16, at 7 p.m., and January 17, at 9.30 a.m., to discuss "Radiation Protection". Particulars can be obtained from the joint honorary secretary of the Industrial Radiology Group of the Institute of Physics, B. R. Byrne, Railway Executive, Research Department, Ashford Works, Kent.

The Aslib Aeronautical Group of technical librarians and information officers serving the aircraft industry will hold its second annual conference at the College of Aeronautics, Cranfield, during March 27-30. Technicians and librarians from Europe, America and the British Commonwealth will be contributing papers, and all who are interested in promoting the efficient exchange of aeronautical information are welcome to attend. Further information can be obtained from the secretary of the Group, Mr. C. W. Cleverdon, College of Aeronautics, Cranfield, Bletchley, Bucks.

A David Anderson-Berry Silver-Gilt Medal and a sum of $£ 100$ is being offered by the Royal Society of Edinburgh to the person who, in the opinion of the Council, has recently produced the best work, published or unpublished, on the therapeutical effect of X-rays on human diseases. Applications, which should be accompanied by relevant papers on the work, must be sent to the General Secretary, Royal Society of Edinburgh, 22 George Street, Edinburgh 2, before March 31.

TнE Medical Research Council is offering a number of fellowships in clinical research, tenable in the United Kingdom during the academic year 1953-54, which are open to suitably qualified medical graduates who desire to prepare themselves for a career in clinical research. The fellowships will be awarded for one year in the first instance, renewable annually up to a maximum of three years, and will carry a stipend of $£ 850$ a year, with annual increments of $£ 75$. Applications must be sponsored in each case by the head of the appropriate department in the candidate's university or medical school. Application forms can be obtained from the Secretary, Medical Research Council, 38 old Queen Street, London, S.W.1, to whom they must be returned not later than March 1 . 